\title{
Population growth of a generational cohort of the copepod Apocyclops panamensis (Marsh, 1913) under different temperatures and salinities
}

\section{Crecimiento poblacional de una cohorte del copépodo Apocyclops panamensis (Marsh, 1913) bajo diferentes salinidades y temperaturas.}

\begin{abstract}
Leonardo Cruz-Rosado [D,
Wilfrido M. Contreras-Sánchez 1 (1)

Ulises Hernández-Vidal ${ }^{1}$ [D

Juan Carlos Perez-Urbiola' 2 ,

María de J Contreras-Garcial@

${ }^{1}$ División Académica de Ciencias

Biológicas, Universidad Juárez

Autónoma de Tabasco, km. 0.5

Carretera Villahermosa-Cárdenas

s/n entronque a Bosques de Saloya,

CP. 86039, Villahermosa, Tabasco,

México.

${ }^{2}$ Centro de Investigaciones Biológicas del Noroeste, P.O. Box 128, La Paz,

B.C.S. 23000 , México.
\end{abstract}

*Corresponding author:

uliseshv44@hotmail.com

\section{Scientific article}

Received: march 05, 2020

Accepted: august 13, 2020

How to cite: Cruz-Rosado L, Contreras-Sánchez WM, HernándezVidal U, Perez-Urbiola JC, ContrerasGarcía MJ (2020) Population growth of a generational cohort of the copepod Apocyclops panamensis (Marsh, 1913) under different temperatures and salinities. Ecosistemas y Recursos Agropecuarios 7(2): e2505. DOI: 10.19136/era.a7n2.2505
ABSTRACT. This study was carried out to identify the effects of salinity and temperature during Apocyclops panamensis culture, fed with Tetraselmis chuii. The experiment was conducted in laboratory conditions for 14 days. Nauplii from the same cohort were used to start the experiment, using a density of 1 ind $\mathrm{mL}^{-1}$ in a volume of $400 \mathrm{~mL}$. The feed consisted of a daily supply of $20000 \mathrm{cell} \mathrm{mL}^{-1}$ of microalgae. Nine treatments with three replicates were evaluated $\left(24^{\circ} \mathrm{C}-28 \%\right.$, $24^{\circ} \mathrm{C}-32 \%$, $24^{\circ} \mathrm{C}-36 \%, 28^{\circ} \mathrm{C}-28 \%, 28^{\circ} \mathrm{C}-32 \%, 28^{\circ} \mathrm{C}-36 \%, 32^{\circ} \mathrm{C}-28 \%$, $32^{\circ} \mathrm{C}-$ $32 \% 0$ and $32^{\circ} \mathrm{C}-36 \% 0$ ). The factorial ANOVA indicates that temperature had a significant effect on the abundance of total copepods at day $14(p=0.02)$, while salinity did not show a significant effect $(p=0.06)$ on the total population of $A$. panamensis. Significant effects of temperature $(p<0.01)$ and salinity $(p<0.001)$ were observed for the nauplii population. The best growth of the entire population was reached in the treatment $32^{\circ} \mathrm{C}-28 \%$, with a population of $1380.95( \pm 1267.06$ ind $L^{-1}( \pm 1267.06)$ at the end of the experiment. Treatments $32^{\circ} \mathrm{C}-28 \%$ and $32{ }^{\circ} \mathrm{C}-32 \%$ produced the highest average population of nauplii and copepodites at the end of the experiment. Adult females presented the greatest abundance in the $32^{\circ} \mathrm{C}-32 \%$ treatment with 214.29 ind $\mathrm{L}^{-1}$, adult males increased between days 11 and 14 in treatments $24^{\circ} \mathrm{C}-28 \%, 32^{\circ} \mathrm{C}-28 \%$, and $32^{\circ} \mathrm{C}-32 \%$ without exceeding 170 ind $\mathrm{L}^{-1}$. In this study, it is evident that $A$. panamensis prefers warm temperatures and brackish environments.

Key words: Copepod culture, environment requeriments, zooplankton.

RESUMEN. El objetivo del estudio fue identificar los efectos de la salinidad y la temperatura durante el cultivo de Apocyclops panamensis, alimentado con Tetraselmis chuii. El experimento se llevó a cabo en condiciones de laboratorio durante 14 días. Se utilizaron nauplios de una misma cohorte, utilizando una densidad de 1 ind $\mathrm{mL}^{-1}$ en un volumen de $400 \mathrm{~mL}$. La alimentación consistió en un suministro diario de 20000 células de microalga $\mathrm{mL}^{-1}$. Se evaluaron nueve tratamientos con tres réplicas $\left(24^{\circ} \mathrm{C}-28 \%, 24^{\circ} \mathrm{C}-32 \%, 24^{\circ} \mathrm{C}-36 \%, 28^{\circ} \mathrm{C}-28 \%\right.$, $28^{\circ} \mathrm{C}-32 \%$, $28^{\circ} \mathrm{C}-36 \%$, $32^{\circ} \mathrm{C}-28 \%$, $32^{\circ} \mathrm{C}-32 \%$ y $32^{\circ} \mathrm{C}-36 \%$ ). El ANOVA factorial indica que la temperatura tuvo un efecto significativo en la abundancia de copépodos totales en el día $14(p=0.02)$, mientras que la salinidad no mostró un efecto significativo $(p=0.06)$ en la población total de $A$. panamensis. Se observaron efectos significativos de la temperatura $(p<0.01)$ y la salinidad $(p<0.001)$ en la población de nauplios. El mejor crecimiento de toda la población al final del experimento se alcanzó en el tratamiento $32^{\circ} \mathrm{C}-28 \%$, con una población de 1 $380.95 \pm 1267.06$ ind $\mathrm{L}^{-1}$. Los tratamientos $32^{\circ} \mathrm{C}-28 \%$ y $32^{\circ} \mathrm{C}-32 \%$ produjeron la mayor población promedio de nauplios y copepoditos al final del experimento. Las hembras adultas presentaron la mayor abundancia en el tratamiento $32^{\circ} \mathrm{C}-32 \%$ con 214.29 ind $\mathrm{L}^{-1}$, los machos adultos aumentaron entre los días 11 y 14 en los tratamientos $24^{\circ} \mathrm{C}-28 \%$, $32^{\circ} \mathrm{C}-28 \%$, y $32^{\circ} \mathrm{C}-32 \%$ sin exceder 170 ind $\mathrm{L}^{-1}$. Los resultados indican que $A$. panamensis prefiere las temperaturas cálidas y los ambientes salobres.

Palabras clave: Cultivo de copépodos, requerimientos ambientales, zooplancton. 


\section{INTRODUCTION}

Planktonic organisms are the basis of the food chain in marine and continental water bodies (Boltovskoy 1981). In marine aquaculture, the use of zooplankton as live food is essential and takes on greater importance during the larval phase, highlighting that it is the best nutritional alternative for the larvae, providing higher survival (Das et al. 2012). In the marine environment, copepods are the most dominant, abundant and widely distributed group of microcrustaceans on the planet, sometimes representing up to $80 \%$ of the total plankton (Melo et al. 2014).

In marine fish culture, rotifers of the genus Brachionus are the most used conventional live food for feeding larvae. As they are very active and smallsized organisms, they attract the attention of their predators, allowing them to be easily captured. In addition, by having a high reproduction rate, short life cycle and feeding based on algae, their cultivation is considerably facilitated (Prieto and Atencio 2008, Onyango 2019, Fuller 2020). However, these organisms do not necessarily complete the nutritional requirements for the optimal development of the marine fish larvae that consume them, generating limited growth. All this can lead to high mortality, possibly due to incomplete nutrition and poor development of the digestive system of the larvae (Luna-Figueroa and Arce 2017, Luna-Figueroa et al. 2018).

Mass production of copepods has been proposed as an alternative to good quality live food in aquaculture (Suárez-Morales 2000, Prieto et al. 2006, Suárez-Morales et al. 2009, Rasdi and Qin 2016, Hansen 2017, Martínez-Silva 2018, Hill et al. 2020). This proposal takes up the principle that the nutritional value of most copepods is high, and their movement patterns provoke a strong food response in larvae of diverse predatory fish species. Other advantages of using copepods as food are high digestibility, small size, and tolerance to good densities during culture. The simple fact that they are part of the natural food of larvae in the wild allows their use in marine fish culture to promote increases in growth, survival, and quality of the larvae that consume them (Prieto et al. 2006,
Martínez-Silva 2018). Nonetheless, when working in aquacultural facilities, it is important to consider that both, rotifers enriched with fatty acids and copepods administered to the fish larvae, increase the possibility of larval survival. The copepods can be considered a nutritional supplement rich in fatty acids.

The quantity, temporality, size, and quality of live food during the larval period are critical to the successful production of marine fish fingerlings. An example of a culture strategy that combines several of these aspects is the so-called mesocosm culture, which has shown promising results by offering a variety of prey that facilitates the larval food transition by imitating what occurs in the wild, and where copepods are a fundamental element (Prieto et al. 2006, Rasdi and Qin 2016, Vu et al. 2017, Wang et al. 2017). The relationship between potential prey and larval selectivity can be approximated by the spatial-temporal coincidence of the two organisms at the spawning sites. An example of this is that the sea herring (Clupea harengus), the red snapper (Lutjanus campechanus), in its larval stage coexists with a high abundance of zooplankton (Álvarez-Fernández et al. 2015, Grüss et al. 2018, Heyman et al. 2019). The Gulf of Mexico (GM) is no exception because it is also considered an important marine fish spawning area determined by its abundance of larvae (FloresCoto et al. 2009, Heyman et al. 2019). ZavalaGarcía et al. (2016) recorded the largest zooplakton biomass ocurring in GM locations during the same season when spawning grounds of Centropomus spp where reported by Hernández-Vidal et al. (2014). This event suggests that some of the zooplankton species present, could play an essential role in nutrition and consequently in larval recruitment in the area.

The copepod Apocyclops panamensis is a species present in these spawning areas on the coasts of the Gulf of Mexico, so that may conform part of the diet of fish larvae in the region. Preliminary studies indicate that it has the potential to be used as live food since it is resistant to manipulation in captivity, been proposed as a candidate for mass cultivation (Phelps et al. 2005, Lindley et al. 2011, Santhosh et al. 2015, Hill et al. 2020). However, the environmental conditions for developing the biotech- 
nology for cultivation on a pilot scale are still unknown. For this reason, the objective of this work was to define the effects of salinity and temperature on the population growth of $A$. panamensis under an aquaculture management scheme that could optimize and eventually allow to scale-up production and prove its effectiveness as live food for marine fish species present in the same distribution range.

\section{MATERIALS AND METHODS}

This research was carried out in the facilities of the Tropical Aquaculture Laboratory (TAL) of the Biological Sciences Academic Division at the Universidad Juárez Autónoma de Tabasco during August and September of 2019.

\section{Collection and preliminary cultivation of zoo- plankton}

Three zooplankton collection trips were made to the coastal zone in Jalapita, municipality of Centla, Tabasco, Mexico, identified as centropomid spawning areas (Gilmore et al. 1983, Hernández-Vidal et al. 2014). The collection sites covered an area ranging from $18^{\circ} 28^{\prime} 34.71^{\prime \prime} \mathrm{N}-92^{\circ} 58^{\prime} 7.34^{\prime \prime} \mathrm{W}$ to $18^{\circ} 26^{\prime} 26.43^{\prime \prime} \mathrm{N}-93^{\circ} 8^{\prime} 4.58^{\prime \prime} \mathrm{W}$, the furthest collection site is $4.7 \mathrm{~km}$ from the coastline, and the nearest is approximately $0.2 \mathrm{~km}$ from the mouth of the Mecoacán coastal lagoon. Surface trawls (1-2 m deep) were conducted using a $120 \mu \mathrm{m}$ mesh plankton net. The zooplankton was placed in $500 \mathrm{~mL}^{-1}$ capacity glass jars with water from the sampling site and then moved to the TAL at low temperature in an icebox. In the laboratory, the living material was screened with a $500 \mu \mathrm{m}$ sieve to remove larger organisms and predators. The remaining organisms were placed in two fiberglass culture tanks with a capacity of $70 \mathrm{~L}$ and were maintained at an average temperature of $25.7 \pm 1.13^{\circ} \mathrm{C}$ and $\mathrm{pH}$ of $7.96 \pm 0.05$ using seawater at the same salinity of the collection site $(32 \%)$. The water was previously filtered with $2 \mu \mathrm{m}$ and treated for $10 \mathrm{~min}$ with a commercial solution of sodium hypochlorite to reach the concentration of $45 \mathrm{ppt}$ and later neutralized by adding $250 \mathrm{mg}$ of sodium thiosulfate $\mathrm{L}^{-1}$. The cultures were fed daily with a mixture of the microalgae Nannochloropsis oculata, Tetraselmis chuii, and T. suecica supplying a total of 8 million cells per experimental unit, equivalent to a density of 20000 cells $\mathrm{mL}^{-1}$. After 20 days of culture, the prevailing zooplankton was recovered with a $50 \mu \mathrm{m}$ sieve that was again maintained for 30 days in conditions similar to those described above.

\section{Isolation and identification}

The isolation of the prevailing copepod species began by separating adult specimens. These organisms were concentrated using a $50 \mu \mathrm{m}$ sieve and under the stereoscopic microscope, and ten adult organisms were isolated. The isolated organisms were kept in 1L-flasks and fed with the previously mentioned algal mixture. This separation of adult organisms was carried out on three occasions, and the organisms were reseeded in new flasks. Samples were fixed in $96 \%$ alcohol added with two drops of glycerin in $5 \mathrm{~mL}$-tubes. Subsequently, they were sent for determination to the Department of Systematics and Aquatic Ecology at El Colegio de la Frontera Sur (ECOSUR) Chetumal Unit, who determined that the isolated species was Apocyclops panamensis. The primary culture was obtained by progressively increasing the volume from the $1 \mathrm{~L}$-culture flasks and maintaining the culture conditions previously described.

\section{Experimental design}

To evaluate population growth, a completely randomized factorial experiment was carried out with three temperature levels $\left(24,28\right.$, and $\left.32{ }^{\circ} \mathrm{C}\right)$ and three salinity levels $(28,32$, and $36 \% 0)$, resulting in nine treatments, each with six replicates. The experimental units consisted of $0.5 \mathrm{~L}$ capacity glass flasks containing a working volume of $400 \mathrm{~mL}$. The culture containers were disinfected by washing with a $0.01 \%$ sodium hypochlorite solution. To achieve and maintain desired temperatures, the experimental units were placed inside $100 \mathrm{~L}$ polyethylene tanks, equipped with two 500-watt and controlled with a thermostat (AQUA-KRIL ${ }^{\circledR}$ 4160). Seawater $(35 \%$ ) was used, previously treated with sodium hypochlorite, and neutralized with sodium thiosulfate. The seawa- 
ter was diluted with sterilized freshwater to reach the salinity of 28 and $32 \%$, to adjust to $36 \%$, commercial sea salt was used (Coral Pro-Red Sea ${ }^{\circledR}$ ). All experimental units were maintained under a photoperiod of $12 \mathrm{~h}: 12 \mathrm{~h}$ (light-dark) controlled with an automatic timer (TEMP 24-HE, STEREN ${ }^{\circledR}$ ). $\mathrm{pH}$ and water temperatures were measured daily using a probe (EcoSense pH10A, YSI USA), while a refractometer was used to measure salinity (Aquafauna ${ }^{\mathrm{TM}}$ Bio-Marine Inc.). Ammonium $\left(\mathrm{NH}_{3}\right)$, nitrites $\left(\mathrm{NO}_{2}\right)$, and nitrates $\left(\mathrm{NO}_{3}\right)$ concentration were measured at the beginning and, subsequently, every five days by colorimetric kits using an aquaculture photometer $(\mathrm{HI}$ 83203, HANNA Instruments).

\section{Copepod stocking}

A cohort of nauplii was obtained from the main population and separated using a $200 \mu \mathrm{m}$ mesh sieve to discard copepodites and adult organisms. The nauplii were placed in a glass beaker with sterilized seawater and the density reached was estimated. Before stocking, the seeds were first acclimated to the desired salinity by decreasing or increasing one unit per hour, and then to temperature, by placing the nauplii in $1 \mathrm{~L}$ flask one hour prior to stocking in each tank with the corresponding temperature. Each experimental unit was stocked with one ind $\mathrm{mL}^{-1}$ for a total of 400 individuals per bottle based on the recommendations of Velásquez et al. (2001).

\section{Feeding}

The feeding was carried out using the microalgae Tetraselmis chuii, according to Velásquez et al. (2001). Initially, each unit was supplied with a total of 8 million cells, equivalent to a density of 20000 cells $\mathrm{mL}^{-1}$. Cultures were used in their maximum growth phase (5-6 days), and the algal density was maintained by counting twice a day and adjusting the preset density when necessary. Microalgae cultures were produced in the Live Food Production Area of the Tropical Aquaculture Laboratory (LAT) at DACBiol using commercial culture medium (PROLINE ${ }^{\circledR}$ ), the cultures were maintained at constant illumination with fluorescent lamps from 2000 to 2500 lux and at a temperature of $24 \pm 1.0^{\circ} \mathrm{C}$.

\section{Counting}

Counts of copepods were performed every third day, taking seven one $\mathrm{mL}$ samples from each experimental unit. The sample was counted using a Bogorov counting chamber (Wildlife Supply model 1810$\mathrm{B} 20 \mathrm{El})$ under a stereoscopic microscope (ZEISS ${ }^{\circledR}$ model Stemi DV4). The stages identified in the culture count were nauplius, copepodite, non-ovigerous female, ovigerous female, and adult male. In addition, the eggs present in the ovarian sacs of the females were counted. The last evaluation of the population was carried out on the 14th day after sowing, which concluded the experiment.

\section{Statistical analysis of data}

The number of organisms per stage was calculated for each treatment, and with the sum of all stages, the value of total copepods (TC) per liter was estimated. After normality and homogeneity of variances were verified (Bartlett's test), the counts obtained at the end of the experiment were compared using a factorial analysis of variance (ANOVA). Significance was determined at the $95 \%$ confidence level $(\alpha=0.05)$. All ANOVAs were performed using the software Statgraphics Centurion XVIII ${ }^{\circledR}$. The graphical representation of the data was done in SigmaPlot v.11 ${ }^{\circledR}$ package. Results are presented in average values per Liter \pm Standard Deviation.

\section{RESULTS}

\section{Environmental conditions during the experiment}

The environmental conditions recorded throughout the experiment were favorable for the development of copepods (Table 1). The temperature varied slightly around the experimental values. The average temperatures prevailing along the experimental units were $24.24 \pm 0.19,27.86 \pm 0.43$, and $31.75 \pm 0.27$. We managed to keep salinity close to the values designated for the study $(28 \pm 0.18,32$ \pm 0.34 and $36 \pm 0.32$ by monitoring twice a day and replacing evaporated water. 


\begin{tabular}{|c|c|c|c|c|c|c|}
\hline $\mathrm{TT}\left({ }^{\circ} \mathrm{C}\right)$ & Sal (ppm) & $\mathrm{NO}_{2}\left(\mathrm{mg} \mathrm{L}^{-1}\right)$ & $\mathrm{NO}_{3}\left(\mathrm{mg} \mathrm{L}^{-1}\right)$ & TAN $\left(\mathrm{mg} \mathrm{L}^{-1}\right)$ & $\mathrm{pH}(\mathrm{IU})$ & $\mathrm{DO}\left(\mathrm{mg} \mathrm{L}^{-1}\right)$ \\
\hline & 28 & $2.30 \pm 1.54$ & $2.47 \pm 4.27$ & $0.37 \pm 0.34$ & $8.12 \pm 0.08$ & $7.17 \pm 0.33$ \\
\hline \multirow[t]{3}{*}{24} & 32 & $0.67 \pm 0.58$ & $4.87 \pm 4.24$ & $0.49 \pm 0.58$ & $8.11 \pm 0.06$ & $6.60 \pm 0.08$ \\
\hline & 36 & $0.33 \pm 0.58$ & $0.63 \pm 1.10$ & $0.47 \pm 0.55$ & $8.10 \pm 0.05$ & $6.54 \pm 0.12$ \\
\hline & 28 & $2.47 \pm 2.54$ & $1.33 \pm 2.31$ & $0.36 \pm 0.35$ & $8.17 \pm 0.09$ & $6.99 \pm 0.24$ \\
\hline \multirow[t]{3}{*}{28} & 32 & $1.97 \pm 0.95$ & $1.77 \pm 1.91$ & $0.51 \pm 0.50$ & $8.15 \pm 0.05$ & $6.92 \pm 0.30$ \\
\hline & 36 & $3.33 \pm 2.08$ & $2.17 \pm 2.20$ & $0.81 \pm 0.95$ & $8.18 \pm 0.08$ & $6.36 \pm 0.16$ \\
\hline & 28 & $1.67 \pm 2.08$ & $1.47 \pm 2.04$ & $0.34 \pm 0.30$ & $8.23 \pm 0.22$ & $5.80 \pm 0.42$ \\
\hline \multirow[t]{2}{*}{32} & 32 & $1.33 \pm 1.50$ & $1.27 \pm 2.19$ & $0.65 \pm 0.61$ & $8.19 \pm 0.09$ & $6.30 \pm 0.18$ \\
\hline & 36 & $2.33 \pm 3.21$ & $3.57 \pm 3.10$ & $0.56 \pm 0.55$ & $8.09 \pm 0.22$ & $6.10 \pm 0.11$ \\
\hline
\end{tabular}

\section{Total counts}

Results from the factorial ANOVA indicate that the temperature had a significant effect on the overall abundance of organisms in the population assessed at day $14(p=0.02)$ and suggests that the evaluated salinities did not have a significant effect on $A$. panamensis production $(\mathrm{p}=0.06)$. In this analysis no effect of the interaction of the factors studied was observed ( $p>0.05)$. The effect of temperature was that, at a temperature of $32{ }^{\circ} \mathrm{C}$, more organisms were obtained ( $888.89 \pm 414.28$ ind $\mathrm{L}^{-1}$ ) being significantly lower at temperatures of 24 and $28{ }^{\circ} \mathrm{C}(293.65 \pm$ 285.72 and $357.14 \pm 264.70$ ind $L^{-1}$, respectively) (Figure 1A). Although salinity was not statistically significant, a distinctive pattern of decrease in the total number of copepods (TC) can be observed as salinity increases, resulting in 722.22 ( \pm 428.57), 500.00 ( \pm $357.14)$ and 317.46 ( \pm 214.29$)$ ind $L^{-1}$ for salinities of 28,32 and $36 \%$, respectively (Figure 1B). At the level of specific treatments, the results of TC indicate that the best productivity of this species at the end of the experiment is reached in treatments $32^{\circ} \mathrm{C}-28 \%$, with a production of $1502.00 \pm 457.74$ ind $\mathrm{L}^{-1}$ and $32^{\circ} \mathrm{C}$ $32 \%$ where $904.76 \pm 576.17$ ind $\mathrm{L}^{-1}$ were obtained (Figure 2). When evaluating the effects on the number of copepodites, non-ovigerous females, ovigerous females and males at the end of the experiment, no statistically significant effects of the factors evaluated or their interaction were observed ( $p>0.10$ in all cases). The specific observations for each group of organisms allowed to follow the trends that contribute so that the treatments $32^{\circ} \mathrm{C}-28 \%$ and $32^{\circ} \mathrm{C}-32 \%$ have reached the highest total populations at the end of the experiment.

Nauplii

The factorial ANOVA for the number of nauplii indicated significant effects of temperature $(P=0.006)$ and salinity $(p=0.001)$, with no interaction between these factors $(p>0.10)$. The $32^{\circ} \mathrm{C}-28 \%$ o treatment had the highest average number of nauplii recorded at the end of the experiment, reaching an average of $738.09 \pm 602.15$ ind $L^{-1}$. The rebound of this treatment began on day eight, when the population reached 452.38 ind $L^{-1}$, by day eleven, the population already had 1142.86 ind $\mathrm{L}^{-1}$. This trend was also observed in the $32^{\circ} \mathrm{C}-32 \%$ treatment, although it was not as pronounced as the previous treatment. In the rest of the treatments, the highest populations did not exceed 400 nauplii $\mathrm{L}^{-1}$, the lowest results being those associated with temperatures of $24^{\circ} \mathrm{C}$ (Figure $3 A)$.

\section{Copepodites}

In general, all treatments showed ups and downs along the trial. The only tendency of increase was observed is in treatment $32^{\circ} \mathrm{C}-28 \%$ for day 11 , having an average of $190.47 \pm 233.28$ ind $\mathrm{L}^{-1}$ and reaching $333.33 \pm 147.54$ ind $L^{-1}$ on day 14. All other treatments remained below 150 ind $\mathrm{L}^{-1}$ (Figure 3B).

\section{Adult females}

The trend analysis of females includes nonovigerous females and ovigerous females, showing high variability in the recorded data. The highest 

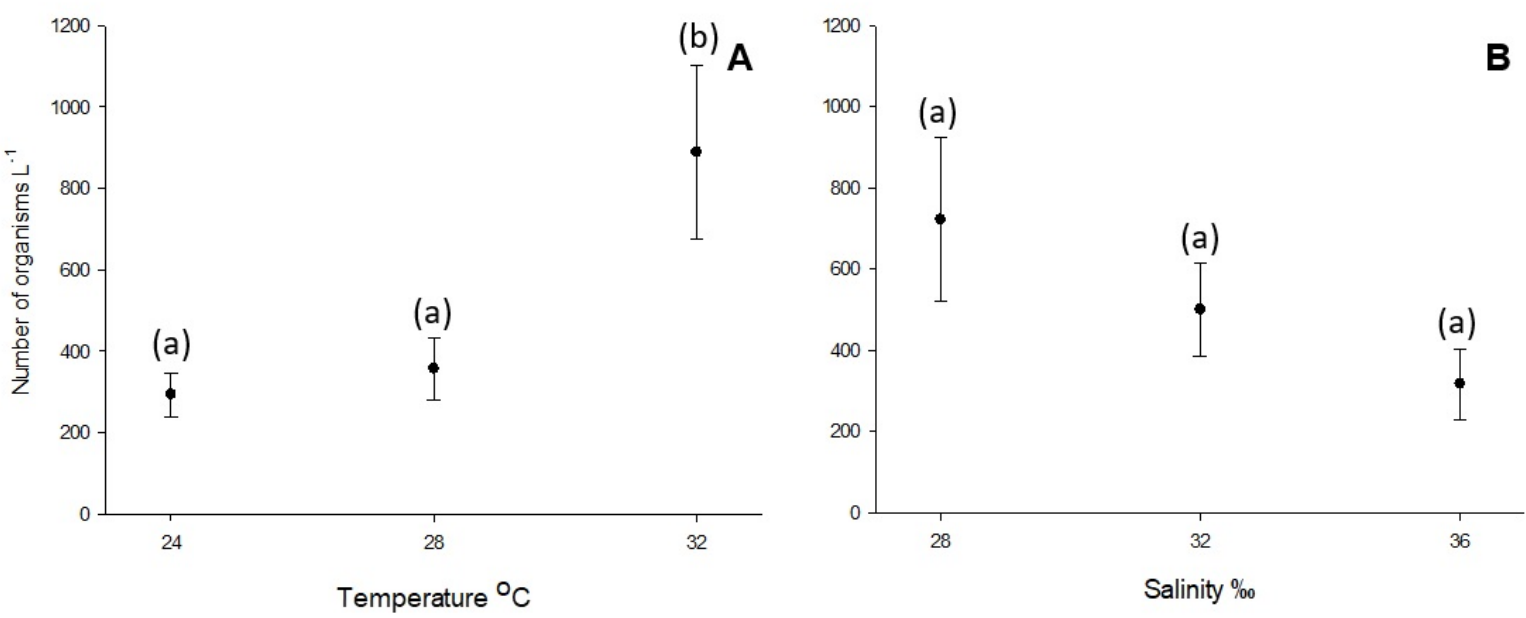

Figure 1. Mean values ( \pm Standard error) of total copepods observed in the three temperatures evaluated $(A)$ and the three salinities $(B)$. Different letters indicate statistically significant differences $(p<0.05)$ between temperatures. The sample size per group is $n=18$.

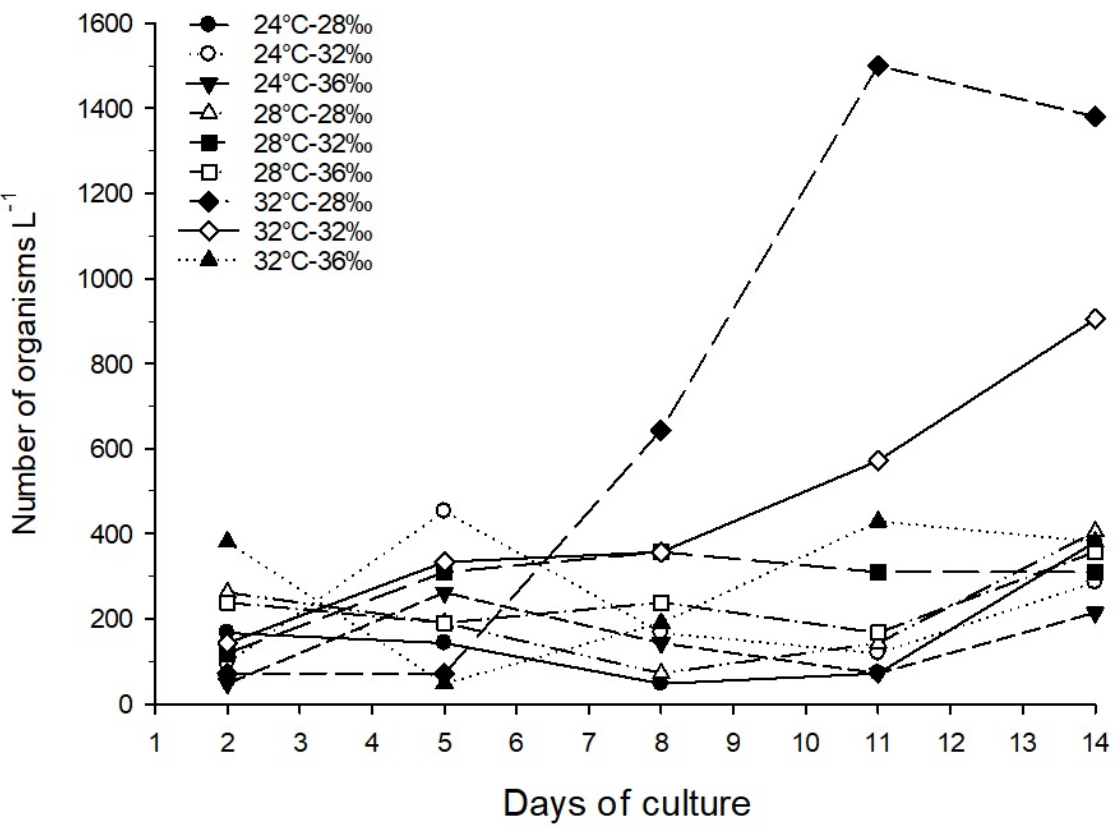

Figure 2. Treatment trends showing mean values of total copepods observed in the nine treatments evaluated. The sample size per observation is $n=6$.

values at the end of the experiment correspond once again to treatments $28^{\circ} \mathrm{C}-32^{\circ} \mathrm{C}-32 \%$ and $32^{\circ} \mathrm{C}-28 \%$ averaging $166.67 \pm 167.01$ and $119.04 \pm 140.46$ ind $L 1$, respectively. The rest of the treatments presented less than 75 ind $\mathrm{L}^{-1}$ (Figure $4 \mathrm{~A}$ ).

\section{Adult males}

The number of adult males remained constant throughout the experiment, with consistent increases observed towards days 11 and 14 in three treatments $\left(24^{\circ} \mathrm{C}-28 \%, 32^{\circ} \mathrm{C}-28 \%\right.$, and $32^{\circ} \mathrm{C}-32 \%$ ) however, none of them exceeded 170 ind $\mathrm{L}^{-1}$. The $24^{\circ} \mathrm{C}-28 \%$ treatment presented the lowest average number of males with 23.81 ( \pm 3.04$)$ ind $L^{-1}$ on day 14 of the experiment (Figure 4B). 


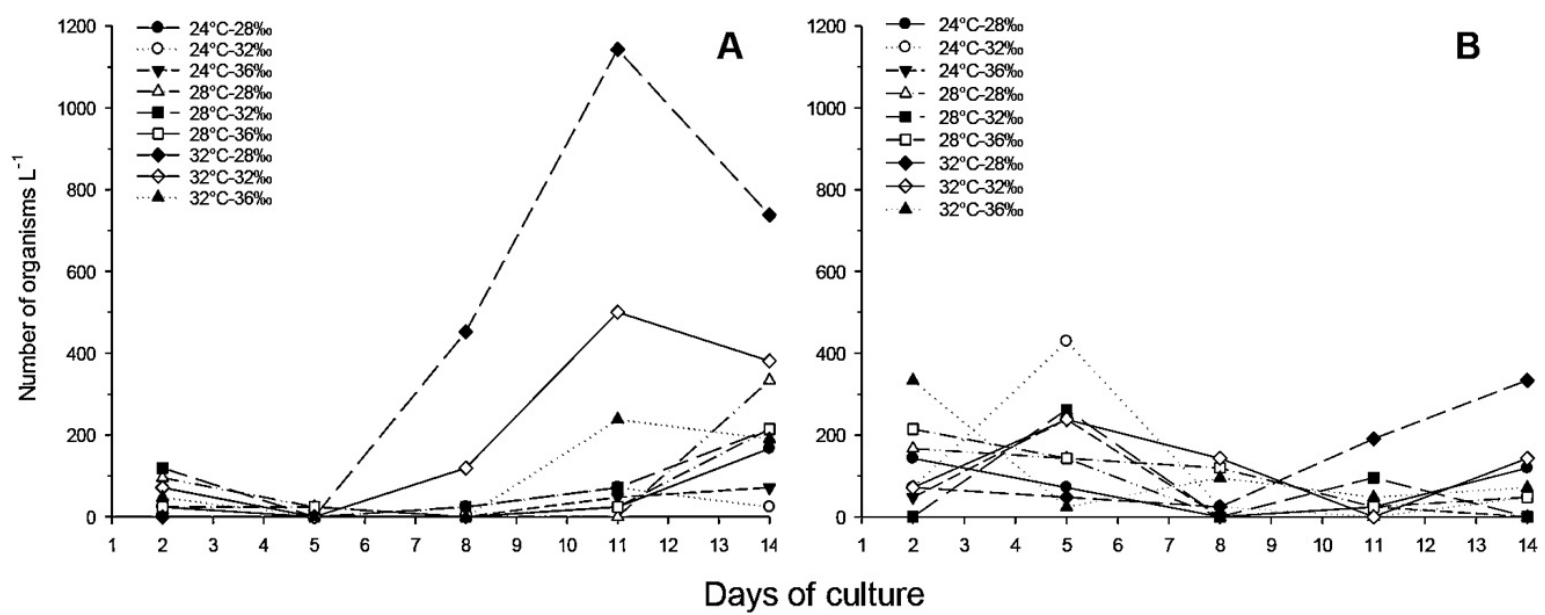

Figure 3. Treatment trends showing mean values of nauplii (A) and copepodites (B) observed in the nine treatments evaluated for 14 days. The sample size per observation is $\mathrm{n}=6$.
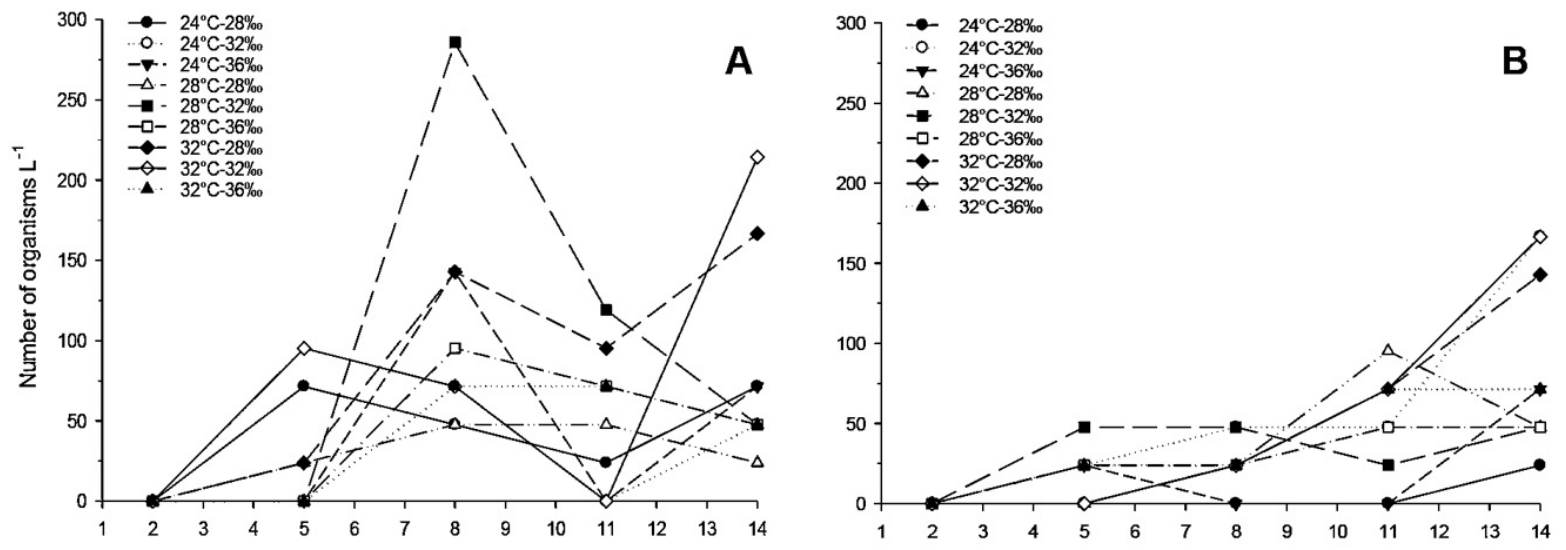

\section{Days of culture}

Figure 4. Treatment trends showing mean values for total females (A) and males (B) observed in the nine treatments evaluated for 14 days. The sample size per observation is $n=6$.

\section{Female:male ratio}

This ratio fluctuated considerably throughout the experiment. During the first five days, no adults were observed in the samplings; these were differentiated from day eight. The highest proportion of females was observed in treatments $28{ }^{\circ} \mathrm{C}-32 \%$ and $32{ }^{\circ} \mathrm{C}-28 \%$ reaching up to six females per male. These values decreased on day 11 , with the highest proportion in the treatment being $28{ }^{\circ} \mathrm{C}-32 \%$ with five females per male. At the end of the experiment (day 14), the ratio female: male varied in treatments between 0.29 and 3.0, averaging between treatments 1.1 females per male.

\section{DISCUSSION}

The population trends observed during 14 days starting from a cohort of nauplii indicate that Apocyclops panamensis grow well under temperatures near $32^{\circ} \mathrm{C}$ and salinities ranging from 28 and $32 \%$ A. panamensis is one of the few species of cy- 
clopoids cultured in the laboratory and recommended for aquacultural practices; however, despite this recommendation, little is known about the specific environmental requirements for this copepod species abundant in the neotropical region (Suárez-Morales et al. 2004). The fact that the two best treatments correspond to the temperature of $32^{\circ} \mathrm{C}$ indicates that this species has better performance under the upper range of temperatures measured in warm-tropical environments. In recent years, we have recorded an average of $29.5^{\circ} \mathrm{C}$ for the warmest months of the year (September-October) near the sites where A. panamensis was collected for the current study, and this corresponds a shallow coastal habitat where is possible to reach high temperature during sunny and wind calm days. Our study suggests that $A$. panamensis like most copepods display a wide tolerance range for temperature fluctuations.

There is a variety of information regarding the effects of temperature on copepod populations, but the leading theory focuses on the direct effects of temperature on fecundity and growth. Warm temperatures promote a fast life cycle, which can translate into high population growth in a short period; this is possible because the duration of the developmental stages and molting rates are physiological processes that are primarily dictated by temperature (Hirst and Bunker 2003, Chailinn et al. 2018). Proof of this is that many tropical Cyclopoid copepods have life cycles lasting from four to five days, making them susceptible to mass cultivation ( $\mathrm{Su}$ et al. 2005, Rasdi et al. 2018). While some species can acclimatize to temperatures outside their normal ranges without inhibiting their reproductive potential (Verbitsky et al. 2017), other species make reproductive adjustments, for example, Acartia tonsa - a temperate climate species - decreases the number of eggs produced by females in cold temperatures (Hansen et al. 2010). Similar results have been reported for $A$. distans, a species belonging to the same genus, whose highest population growth was achieved under a temperature range of 26 to $33.8^{\circ} \mathrm{C}$.

Salinity is another of the environmental parameters that strongly influence the ecological and biological responses of copepods (Pan et al. 2016).
In this experiment, it becomes evident that $A$. panamensis is well adapted to a relatively wide range of salinities; however, population growth displays best results at $28 \%$, particularly for the naupliar stage. This species is considered euryhaline since it has been reported in environments ranging from the oligohaline condition that occurs in coastal lagoons and estuaries to hypersaline waters in semi-desert areas of North America (Pérez et al. 2006, Reid and Hribar 2006, Annabi-Trabelsi et al. 2019). The wide tolerance of the species has also been demonstrated by being collected in salinity of $6.6 \%$ and later successfully acclimatized to $30 \%$ (Lindley et al. 2011, Roy and Venkataraman 2018). It is inferred that it is a species that tolerates wide ranges of salinity, with a preference for brackish water as observed in this experiment. Even though euryhaline species can survive under a wide range of salinities, reproductive performance can be affected severely depending on this parameter leading to unsustainable population growth and ultimately result in copepod mortality (Pan et al. 2016). Reid et al. (2002) and FuentesReinés and Suárez-Morales (2015) considered that the genus Apocyclops is so ubiquitous that can be observed dominating plankton communities in coastal lagoons, saline lakes, and coastal marshes. However, it is frequently associated with salinities under $30 \%$. In our experiment, all treatments having 32\% resulted in reduced production of nauplii. This response to higher salinity levels is explained by Kimmel and Bradley (2001) and Pan et al. (2016) as a result of a shift in the energy budget for reproduction towards energy needed for adjusting the metabolism required for osmoregulation. The fact that we have registered population growth in the various conditions evaluated is proof of the vast adaptive capacity of $A$. panamensis.

In general for this group of organisms, it is known that adults have tolerance to several factors considered adverse as well as their latency stages since this facilitates dissemination by means of birds and wind, which could be the explanation of the successful colonization of contrasting environments in which they have been found, although little is known about the physiological and ecological mechanisms 
that allow copepods to reside in these environments (Anufriieva 2015).

In the best treatment of this study $\left(32^{\circ} \mathrm{C}-28 \%\right)$, it was observed that the population grew 3.4 times in 14 days, reflecting rapid growth. These results are similar to other studies where Cyclopoid production has commonly been generated from 1 to 5 times the amount inoculated (Pérez et al. 2006, Farhadian et al. 2008, Ruiz-Guzmán et al. 2012). In an extreme case, Velásquez et al. (2001) reported a growth in the culture of $A$. distans of up to 27 times what was stocked for ten days using ambient temperature (26.0 $-38.8^{\circ} \mathrm{C}$ ), salinity around $40 \%$ and total darkness for their best treatment. The high productivity observed in our treatments mainly reflects the number of nauplii obtained, which are the objective for the aquaculture of fish larvae.

The obtained productivity of 738 nauplii $\mathrm{L}^{-1}$ is a moderate nauplii production when compared to values obtained by Phelps et al. (2005) in the experimental culture of $A$. panamensis using adult copepods in initial densities of 320, 1280 and up to 5120 adults $L^{-1}$ for a period of 4 to 9 days. In that study, the author produced 16942 nauplii $\mathrm{L}^{-1}$ in the maximum density of adults stocked. These differences could be atribuible to culture procedures and stages stocked, but suggest potential for nauplii production in $A$. panamensis under our defined environmental conditions.

Another factor that could have contributed to the productivity observed in $A$. panamensis is the type of food used. Tetraselmis chuii is considered an excellent food alternative for copepods, because they are mobile flagellated algae of considerable size, having a notorious preference in comparison with non-mobile algae. Velásquez et al. (2001) obtained the best production values of nauplii in $A$. distans using Tetraselmis chuii when compared with $N$. oculata. The cell density used in this study can be considered as low (20000 cell $\mathrm{mL}^{-1}$ ) compared to other studies where $50,000 \mathrm{cell} \mathrm{mL}^{-1}$ (Pérez et al. 2006) to 600000 cell mL $^{-1}$ (Mujica et al. 1995) are used. Velásquez et al. (2001) used algae densities of 300000 cell $\mathrm{mL}^{-1}$ of $T$. chuii to feed $A$. distans, while Ruiz-Guzmán et al. (2012) obtained the best results in the cultivation of Cyclopina sp. with the combination of $T$. suecica and Isochrysis galbana. The cell density of 600000 cell $\mathrm{mL}^{-1}$, gave favorable results in the culture of Tigriopus sp. supplying Nannochloropsis sp. (Mujica et al. 1995). Phelps et al. (2005) cultivated A. panamensis using a cell density of 500000 cell $\mathrm{mL}^{-1}$ using the microalgae Isochrysis galbana. The production of $A$. panamensis could be improved by using a varied diet, possibly favoring the productivity of copepod crops compared to feeding using a single species. This can be attributed to the high content of polyunsaturated fatty acids provided by the mixtures (Farhadian 2008). Alternatively, these algal diets can be improved by supplying other food sources such as flours of vegetable and animal origin, as well as inorganic fertilizers and using culture protocols such as mesocosm resulting in a good nutritional profile (Phelps et al. 2005, Prieto et al. 2006).

Copepods play an important role in the initial stages of development of marine fish because they constitute their main natural prey, in addition to having a high nutritive content, easy digestion and adequate transfer of nutrients, making them an important food source in aquaculture (Ruiz-Guzmán et al. 2012). Copepod nauplii are a rich source of free amino acids (FAA) and contain more than twice the amount of FAA than Artemia, and higher levels of HUFA (Naess et al. 1995, Rayner et al. 2017). Proof of this nutritional value is that copepods are used in the larval stage of turbot Scophthalmus maximus (Bruno et al. 2018) Atlantic cod Gadus morhua (Karlsen et al. 2015), red snapper Lutjanus campechanus (Phelps et al. 2005) and the gilt-head sea bream Sparus aurata (Mona et al. 2019). All these species proved to be successful predators of all stages of copepods of the orders Harpacticoida and Cyclopoida, demonstrating the potential of copepod cultivation by improving the nutritional quality of the diet and decreasing dependence on rotifers and artemia (Vanacor-Barroso et al. 2017). Data for FAA content in $A$. panamensis indicate that nutritional profile is similar to other copepod species used actually on larviculture (Lindley et al. 2011).

Copepods can be cultivated at high densities, and that their cultivation is relatively easy (Ribeiro and Souza-Santos 2011). They have even been 
successfully cultivated in recirculation systems where the production has been exclusively of nauplii and copepodites, stages that are used in the feeding of marine fish larvae (Buttino et al. 2012). In a recent study, we found that $A$. panamensis maintained at $28 \% 0$ and $32^{\circ} \mathrm{C}$ accomplishes its life cycle in six days (data not shown) and reached 11600 copepods $\mathrm{L}^{-1}$ in a $1000 \mathrm{~L}$ tank. With these preliminary results, $A$. panamensis can be considered as a good candidate for mass culture protocol evaluations in order to determine conditions for pilot-scale production (Ribeiro and Souza-Santos 2011, Hansen et al. 2017). Previous experiences by Phelps (2005) in A. panamensis cultured in earthen ponds indicate feasibility for mass production on this species; however, more information about the optimal conditions of variables in the culture system is necessary. The results presented here provide valuable information for $A$. panamensis culture, because the definition of preferred temperatures and salinities for a particular species, provide conditions where the organisms are subject to minimum stress; their physiological functions are optimized, providing a maximum population growth (Nichelmann 1983, Verbitsky et al. 2017). These data can be suitable for production protocols evaluations.

\section{CONCLUSIONS}

The species Apocyclops panamensis has a preference for warm waters $\left(32^{\circ} \mathrm{C}\right)$ and medium salinity $(28-32 \% 0)$. The high production capacity of
A. panamensis observed in this experiment allows visualizing the potential for scaling up production and evaluation as live food for larval culture of tropical fish. Nauplii and copepodites can be an alternative for feeding larval stages of marine fishes due to their small sizes. Another convenient feature is that it has a short life cycle that makes them susceptible to rapid mass production. We consider that $A$. panamensis is a species suitable to be used as live food; however, it is required to demonstrate its viability for mass production at pilot scale and preference by larvae of different species of fish.

\section{ACKNOWLEDGEMENTS}

Authors thank the anglers from the Sociedad Cooperativa de Pescadores "San Ramón" Tabasco, especially Ramón Domínguez-Sánchez for his invaluable logistic support during our biological samplings. This investigation was a part of the Aquaculture Collaborative Research Support Program, supported partly by the United States Agency for Internal Development (USAID) (LAG-G-00-96-90015$00)$. The opinions expressed herein are those of the authors and do not necessarily reflect the views of the AquaFish Innovation Lab or USAID. CONACyT provided a Ph.D. scholarship to Leonardo CruzRosado (258602). W.M.C.S. is a grant holder from SNI-CONACyT.

\section{LITERATURE CITED}

Álvarez-Fernández S, Licandro P, Van Damme CJG, Hufnagl M (2015) Effect of zooplankton on fish larval abundance and distribution: a long-term study on North Sea herring (Clupea harengus). ICES Journal of Marine Science 72: 2569-2577.

Annabi-Trabelsi N, El-Shabrawy G, Goher ME, Subrahmanyam MNV, Al-Enezi Y, Ali M, Ayadi H, Belmonte G (2019) Key Drivers for Copepod Assemblages in a Eutrophic Coastal Brackish Lake. Water 11: 2-20.

Anufriieva EV (2015) Do copepods inhabit hypersaline waters worldwide? A short review and discussion. Chinese Journal of Oceanology and Limnology 33: 1354-1361.

Boltovskoy D (1981) Atlas del Atlántico Sudoccidental y métodos de trabajo con el zooplancton marino. Mar del Plata. INIDEP. Argentina. 936p. 
Bruno E, Højgaard JK, Hansen BW, Munk P, Støttrup JG (2018) Influence of swimming behavior of copepod nauplii on feeding of larval turbot (Scophthalmus maximus). Aquaculture International 26: 225-236.

Buttino I, lanora A, Buono S, Vitiello V, Malzone MG, Rico C, Langellotti AL, Sansone G, Gennari L, Miralto A (2012) Experimental cultivation of the Mediterranean calanoid copepods Temora stylifera and Centropages typicus in a pilot re-circulating system. Aquaculture Research 43: 247-259.

Chailinn P, Ju SJ, Park W, Kim HW, Lee SR, Park JH (2018) The strategy of population maintenance by coastal copepod inferred from seasonal variations in abundance of adults and resting eggs. Ocean and Polar Research 40: 213-222.

Das P, Mandal SC, Bhagabati SK, Akhtar MS, Singh S K (2012) Important live food organisms and their role in aquaculture. Frontiers in Aquaculture 4: 69-86.

Farhadian O, Yusoff FM, Arshad A (2008) Population growth and production of Apocyclops dengizicus (Copepoda: Cyclopoida) fed on different diets. Journal of World Aquaculture Society 39: 384-396.

Flores-Coto C, Espinosa-Fuentes M, Zavala-García F, Sanvicente-Añorve L (2009) Ictioplancton del sur del Golfo de México: Un compendio. Hidrobiológica 19: 49-76

Fuentes-Reinés JM, Suárez-Morales E (2015) Checklist of planktonic copepoda from a colombian coastal lagoon with record of Halicyclops exiguus kiefer. Boletín de Investigaciones Marinas y Costeras - INVEMAR 44: 369-389.

Fuller SA (2020) Minimizing time fed rotifers maximizes hybrid striped bass larval growth in recirculating aquaculture systems. North American Journal of Aquaculture 2: 208-214.

Gilmore RG, Donohoe CJ, Cooke DW (1983) Observations on the distribution and biology of east-central Florida populations of the common snook, Centropomus undecimalis (Bloch). Florida Scientist 46: 313-336.

Grüss A, Biggs C, Heyman WD, Erisman B (2018) Prioritizing monitoring and conservation efforts for fish spawning aggregations in the US Gulf of Mexico. Fisheries.Research 213: 75-93.

Hansen B W, Drillet G, Kozmér A, Madsen KV, Pedersen MF, Sørensen TF (2010) Temperature effects on copepod egg hatching: does acclimatization matter? Journal of Plankton Research 32: 305-315.

Hansen BW (2017) Advances using copepods in aquaculture. Journal of Plankton Research 39: 972 ?974.

Hansen BW, Hansen PJ, Nielsen TG, Jepsen PM (2017) Effects of elevated pH on marine copepods in mass cultivation systems: Practical implications. Journal of Plankton Research 39: 984-993.

Hernández-Vidal U, Chiappa-Carrara X, Contreras-Sánchez W (2014) Reproductive variability of the common snook, Centropomus undecimalis, in environments of contrasting salinities interconnected by the GrijalvaUsumacinta fluvial system. Ciencias Marinas 40: 173-185.

Heyman WD, Grüss A, Biggs CR, Kobara SI, Farmer NA, Karnauskas M, Lowerre-Barbieri S, Erisman B (2019) Cooperative monitoring, assess-ment, and management of fish spawning agg regations and associated fisheries in the U.S. Gulf of Mexico. Marine Policy 109: 103689. Doi: 10.1016/j.marpol.2019.103689.

Hill M, Pernetta A, Crooks N (2020) Size matters: A review of live feeds used in the culture of marine ornamental fish. Asian Fisheries Science 33: 161-174.

Hirst AG, Bunker AJ (2003) Growth of marine planktonic copepods: global rates and patterns in relation to chlorophyll a, temperature, and body weight. Limnology Oceanography 48: 1988-2010. 
Karlsen Ø, Van Der MT, Rønnestad I, Mangor-Jensen A, Galloway TF, Kjørsvik E, Hamre K (2015) Copepods enhance nutritional status, growth and development in Atlantic cod (Gadus morhua L.) larvae-can we identify the underlying factors? PeerJ 3: e902. Doi. 10.7717/peerj.902.

Kimmel DG, Bradley BP (2001) Specific protein responses in the calanoid copepod Eurytemora affinis (Poppe, 1880) to salinity and temperature variation. Journal of Experimental Marine Biology and Ecology 266: 135149.

Lindley LC, Phelps RP, Davis DA, Cummins KA (2011) Salinity acclimation and free amino acid enrichment of copepod nauplii for first-feeding of larval marine fish. Aquaculture 318: 402-406.

Luna-Figueroa J, Arce UE (2017) Un menú diverso y nutritivo en la dieta de peces: "el alimento vivo". Agro Productividad 10: 112-116

Luna-Figueroa J, Arce UE, Figueroa TJ (2018) Ventajas e inconvenientes del uso de alimento vivo en la nutrición de peces. Inventio 14: 39-43.

Martínez-Silva MA, Audet C, Winkler G, Tremblay R (2018) Prey quality impact on the feeding behavior and lipid composition of winter flounder (Pseudopleuronectes americanus) larvae. Aquaculture and Fisheries. 3: 145-155.

Melo PAMC, de Melo J MDM, Macêdo SJ, Araujo M, Neumann-Leitao S (2014) Copepod distribution and production in a Mid-Atlantic Ridge archipelago. Anais da Academia Brasileira de Ciências 4: 1719-1733.

Mona MH, Rizk EST, El-feky MM, Elawany ME (2019) Effect of nutritional quality of rotifers and copepods on sea bream (Sparus aurata) fry fish productivity. The Egyptian Journal of Experimental Biology 15: 135-142.

Mujica AR, Carvajal UC, Miranda EO (1995) Cultivo experimental de Tigriopus sp. (Copepoda: Harpacticoidea). Investigaciones Marinas 23: 75-82.

Naess T, Germain-Henry M, Naas KE (1995) First feeding of Atlantic halibut (Hippoglossus hippoglossus) using different combinations of Artemia and wild zooplankton. Aquaculture 130: 235-250.

Nichelmann M (1983) Some characteristics of the biological optimum temperature. Journal of Thermal Biology 8 : 69-71.

Onyango OC (2019) The mass culture of the freshwater rotifers Brachionus rubens Ehrenberg 1838 using different Algal species diets United International Journal for Research \& Technology 1:1-15.

Pan YJ, Souissi A, Souissi S, Hwang JS (2016) Effects of salinity on the reproductive performance of Apocyclops royi (Copepoda, Cyclopoida). Journal of experimental Marine Biology and Ecology 475: 108-113.

Pérez IE, Gómez NS, Puello-Cruz AC (2006) Efecto de diferentes dietas de microalgas sobre la supervivencia y crecimiento de Apocyclops aff. panamensis (Marsh, 1913), (Copépodo: Cyclopoida) cultivado bajo condiciones controladas de laboratorio. Revista Electronica de Veterinaria 7:1-10.

Phelps RP, Sumiarsa S, Lipman EE, Lan HP, Moss KK, Davis AD (2005) Intensive and extensive production techniques to provide copepod nauplii for feeding larval red snapper Lutjanus campechanus. In: ChengSheng L, O’Bryen P, Marcus N (ed) Copepods in aquaculture Wiley-Blackwell. US. pp: 151-168.

Prieto M, Atencio V (2008) Zooplancton en la larvicultura de peces neotropicales. Revista MVZ Cordoba 13:14151415.

Prieto M, Castaño F, Sierra J, Logato P, Botero J (2006) Alimento vivo en la larvicultura de peces marinos: copépodos y mesocosmos. Revista MVZ Córdoba 11: 30-36. 
Rasdi NW, Qin JG (2016) Improvement of copepod nutritional quality as live food for aquaculture: a review. Aquaculture Research 47: 1-20.

Rasdi NW, Suhaimi H, Yuslan A, Sung YY, Ikhwanuddin, Omar SS, Qin JG, Kassim Z, Yusoff FM (2018) Effect of mono and binary diets on growth and reproduction of cyclopoid copepod. Aquaculture, Aquarium, Conservation and Legislation 11: 1658-1671.

Rayner TA, Jørgensen NOG, Drillet G, Hansen, BW (2017) Changes in free amino acid content during naupliar development of the calanoid copepod Acartia tonsa. Comparative Biochemistry and Physiology Part A: Molecular and Integrative Physiology 210: 1-6.

Reid JW, Hamilton IV R, Duffield RM (2002) First confirmed New World record of Apocyclops dengizicus (Lepeshkin), with a key to the species of Apocyclops in North America and the Caribbean region (Crustacea: Copepoda: Cyclopidae). Jeffersoniana 10: 1-25.

Reid JW, Hribar LJ (2006) Records of some Copepoda (Crustacea) from the Florida Keys. Proceedings of the Academy of Natural Sciences of Philadelphia. Jeffersoniana 155: 1-8.

Ribeiro AC, Souza-Santos LP (2011) Mass culture and offspring production of marine harpacticoid copepod Tisbe biminiensis. Aquaculture 321: 280-288.

Roy MD, Venkataraman K (2018) Catalogue on copepod fauna of India. part 2. cyclopoida and harpacticoida (arthropoda: crustacea). Journal of Environment and Sociobiology 15: 109-194.

Ruiz-Guzmán JA, Jiménez CA, Gomes C, Prieto MJ (2012) Cultivo experimental de Cyclopina sp. con diferentes especies de microalgas. Revista Colombiana de Ciencias Pecuarias 25: 97-105.

Santhosh BF, Anzeer FM, Unnikrishnan C, Anil MK (2015) Potential species of copepods for marine finfish hatchery. In: Vizhinjam Research Centre of CMFRI (ed). Teaching Resource. Vizhinjam. pp: 170-176.

Su HM, Cheng SH, Chen TI, Su MS (2005) Culture of copepods and applications to marine finfish larval rearing in Taiwan. In: Cheng-Sheng L, O'Bryen P, Marcus N (ed) Copepods in aquaculture. Wiley-Blackwell US. Pp: 183-194.

Suárez-Morales E (2000) Copépodos, seres ubicuos y poco conocidos. Biodiversitas 29: 7-11.

Suárez-Morales E, Fleeger JW, Montagna PA (2009) Free-living Copepoda (Crustacea) of the Gulf of Mexico. In: Felder DL, Camp DK, Cato JC, Buster NA, Holmes ChW, Day JW, Yáñez AA, Bianchi TS (ed.) Gulf of Mexico origin, Waters and Biota. Vol 1. College Station, Texas, United States : Texas A\&M University Press. USA. pp: 841-870.

Suárez-Morales E, Reid JW, Fiers F, lliffe TM (2004) Historical biogeography and distribution of the freshwater cyclopine copepods (Copepoda, Cyclopoida, Cyclopinae) of the Yucatan Peninsula, Mexico. Journal Biogeography 31: 1051-1063.

Vanacor-Barroso M, Carvalho CVAD, Antoniassi R, Ronzani-Cerqueira V (2017) The copepod Acartia tonsa as live feed for fat snook (Centropomus parallelus) larvae from notochord flexion to advanced metamorphosis. Latin American Journal of Aquatic Research 45: 159-166.

Velásquez A, Rosas J, Cabrera T, Millán J, Hernández M (2001) Efecto de Tetraselmis chuii, Nannochloris oculata y Dunaliella salina sobre el crecimiento poblacional de Apocyclops distans (Copepoda, Cyclopoidae) en diferentes condiciones de temperatura e iluminación. Revista de Biología Marina y Oceanografía 36: 189197. 
Verbitsky VB, Grishanin AK, Malysheva OA, Medyantseva EN, Verbitskaya TI (2017) Thermal resistance, preferred and avoidance temperatures of Cyclops strenuus Fischer, 1851, and their relation to optimal, pessimal, and tolerant temperatures. Biology Bulletin 44: 439-448.

Vu MTT, Hansen BW, Kiørboe T (2017) The constrains of high density production of the calanoid copepod Acartia tonsa Dana. Journal of Plankton Research 39: 1028-1039.

Wang KLK, Shao J, HU W (2017) Yeast and corn flour supplement to enhance large-scale culture efficiency of marine copepod Tisbe furcata, a potential live food for fish larvae. Israeli Journal of Aquaculture-Bamidgeh 69: 1-8.

Zavala-García F, Flores-Coto C, De la Luz Espinosa-Fuentes M (2016) Relationship between zooplankton biomass and continental water discharges in the southern Gulf of Mexico (1984-2001). Revista de Biología Marina y Oceanografía 51: 21-31. 